University of Nebraska - Lincoln

DigitalCommons@University of Nebraska - Lincoln

Russian Language and Literature Papers

Modern Languages and Literatures, Department

1990

\title{
Harmonious Compositions: Korolenko's Siberian Stories
}

Radha Balasubramanian

University of Nebraska - Lincoln, rbalasub@unlnotes.unl.edu

Follow this and additional works at: https://digitalcommons.unl.edu/modlangrussian

Part of the Modern Languages Commons

Balasubramanian, Radha, "Harmonious Compositions: Korolenko's Siberian Stories" (1990). Russian Language and Literature Papers. 6.

https://digitalcommons.unl.edu/modlangrussian/6

This Article is brought to you for free and open access by the Modern Languages and Literatures, Department of at DigitalCommons@University of Nebraska - Lincoln. It has been accepted for inclusion in Russian Language and Literature Papers by an authorized administrator of DigitalCommons@University of Nebraska - Lincoln. 


\title{
Harmonious Compositions: Korolenko's Siberian Stories
}

\author{
Radha Balasubramanian \\ University of Nebraska
}

Vladimir Galaktionovich Korolenko (1853-1921) turned his personal experiences as a political prisoner in Siberia into short stories that champion the talents of Siberia's ordinary people.

These stories of Siberia have been noted by critics for their techniques of composition. His contemporaries like A. P. Chekhov and V. M. Garshin praise his craftsmanship and skill to compose aesthetically appealing short stories. ${ }^{1}$ Leighton shows how Korolenko, in order to reveal and document facts about different human beings, utilizes various literary devices such as particularized narration (skaz), allegory, contrast, parallel, and lyrical description. ${ }^{2}$ According to him, each story is like an "elegant, polished, graceful and harmonious composition" where the various literary devices are used "instinctively" (201). But I think that Korolenko organizes nature description, surroundings, atmosphere, and action of the narrative to complement the choice of heroes deliberately to create the harmony that Lunacharskii discusses (6-8). My essay indeed takes off from Lunacharskii's abstract observations and shows that Korolenko deftly employs narrative techniques and achieves a harmony between the narrator and character and their relationship to nature.

Korolenko's Siberian stories form a homogeneous group of sixteen stories written in two cycles. The first one, made up of "The Strange One" (1880), "Iashka" (1880), "The Murderer" (1882), "Makar's Dream" (1883), "Sokolinets" (1885), "The Prison" (1886), "Fedor Bespriiutnyi" (1886), "The Circassian" (1888), was written during and immediately after Korolenko's exile. The other cycle, which consists of "Temptation" (1891), "At-Davan" (1892), "Marusia's Settlement" (1899), "Lights" (1900), "The Last Ray" (1900), "The Frost" (1900-1901), "The Coachmen, Lords" (1900), "The Feudal Lords" (1904), was written later in life after a lapse of a decade or more since his exile to Siberia. Clearly, Siberia as a theme continues to occupy Korolenko throughout his writing career; even in the 1890 s he goes back to his notes and memories to reconstruct a few more pieces about it. It is only after he exhausts the stories of Siberia in 1904-the year that his last story of Siberia ("The Feudal Lords") was written-that he turns to writing his memoirs, A History of My Contemporary (1905-1921). After 1905 there is a sharp decline in the number of stories that Korolenko 
wrote, suggesting that his motivation and inspiration for writing fiction diminished.

The stories concentrate on portraying the Siberian inhabitants and their life styles. Sometimes the bureaucratic corruption reigning in the administration in Siberia is exposed (e.g., "The Murderer," "The Feudal Lords," "The Coachmen, Lords"). In others, the characters want to be free from the dreary surroundings (e.g., "The Strange One," "Iashka," "Fedor Bespriiutnyi"). The relationship between the people and the intelligentsia becomes an important problem in some stories (e.g., "The Strange One," "The Frost," "Fedor Bespriiutnyi"). Whatever the main conflict in the stories, Korolenko usually highlights the talents that the simple people in Siberia possess. Korolenko's main concern is to reveal the totality of human beings-their strengths and weaknesses.

The characters invariably live close to nature and find in it the will and strength to live. They constantly interact with nature, while they also have an independent existence of their own. The moral quest of the narrator, who often is a participant, takes the form of a search in those faraway places for protagonists among the simple folk whose strength, humility, courage, and independence he admires but does not yet fully comprehend. Once he locates them, his poetic prose vividly portrays these people in harmony with the formidable, hitherto unexplored, potentially rich landscape of Siberia-in other words he draws a parallel between the "lives of nature and man." 3 Then the narrator begins investigating what drives them to live the life that they have chosen and he finds that a deep underlying code governs their actions. In the process he understands that "heroic moment in the simple man's life" 4 which has shaped the further course of his own life. These revelations of the crises in the lives of his characters are presented through a personalized narrator.

The narrator depicts the characters and the scene in both firstperson and third-person narratives with a very distinct and recognizable voice. The first-person narrator usually takes the mask of a traveler, a minor character who observes and listens to the characters from within the space he shares with them, as in "The Strange One." In third-person narratives the narrator is either omniscient, authoritatively describing the plight of his heroes from inside the characters' positions, as in "Makar's Dream," or he chooses a surrogate in the story who interacts with the characters and describes them from the same shared situation as Fedor Bespriiutnyi does in the story of the same name.

In each of these stories the narrator's voice sets the tone and the mood with a description of the environment surrounding him and the characters in order to reveal their inner personality. The narrator 
typically begins most of the Siberian stories with "symbolic overtures,"5 creating a feeling of restlessness both in nature and the characters' minds as if to predict a change or a crisis. For example, the openings of the stories "The Strange One": "It is getting colder, the evening is settling" (3) 6 and "Sokolinets": "I was engulfed by the silence and gloom as the northern day was extinguishing and a cold wintry storm was approaching" (131) make both the narrator and the character wonder what they need to do to withstand the sudden change. They realize that their strength will be tested. These openings concentrate on giving a sense of the narrator's or the hero's awe at the formidable expanse he witnesses and of his struggle to understand the untamed beauty of Siberia. Nature overpowers the observer's emotions with an imminent transformation: a snowstorm intensifies, rain-bearing clouds darken. Then the elemental powers are seen in furious action, turning man into a silent, powerless observer. Often the narrator and the characters traveling under those worsening conditions are forced to look for shelter. Trapped together in a temporary shelter, not knowing what the outcome of nature's fury will be, the narrator and the characters wait, watch, and anticipate. They find a common denominator in their shared situation, and the similarity of their hopes and fears emerges in their minds. Then they find themselves involuntarily reassessing their lives, as if they realize the temporariness of their existence. They remember those significant incidents from their pasts when their courage and convictions were tested or when their actions decided the course of their future lives. Thus the characters reminisce about a principle, a belief, a feeling, or a dream that they have held deep in themselves and which now surfaces, as if the storm outside has evoked a parallel storm inside.

In most of the stories the weather deteriorates further as the day gives way to the darkness of night. The outside forces become congenial for unexpected memorable encounters between the narrator and his fellow travelers. The narrator is then drawn to characters who stand out from the crowd either because of their "unacceptable profession" (wanderer in "Fedor Bespriiutnyi") or because of their resolute stance (Old-Believer in "Iashka"). Upon settling down with the characters in a shelter for a short time, he concentrates on striking up a conversation with them so as to reveal the personalities of these unusual people who are often outwardly simple, but inwardly powerful.

Most of the characters, like the narrator, are driven by a spirit to wander. Some are wanderers in the real sense (like Fedor in "Fedor Bespriiutnyi," Bagilai in "Sokolinets"), and some are wanderers because of their profession (like the first-person narrator in all firstperson-narrated stories and the policeman in "The Strange One") which requires them to travel from place to place without a fixed route or a 
definite destination. There are still others who feel like outsiders in the community where they live and wish to go somewhere far away. Makar in "Makar's Dream" hopes to "abandon everything and go away to the mountains. ... What this mountain was, where it was, he did not know exactly; he knew only that, first, this mountain existed, and second, that it was somewhere far away ..." (104).

The free, loving spirit that dictates the characters' aspirations and actions is outside the conventional norms of society. With each one of the Siberian heroes the narrator tries to discover the essence of his courage, that which shapes or has shaped his existence. Even Makar, one of the most timid, voiceless victims of society, fulfills his desire to escape into freedom and go far away in his dream: there in heaven, as if reborn, he admits to his sins and justifies himself, at the same time showing that he has been able to do nothing more than suffer helplessly. The rhetorical question he asks of the god Toion after describing his pitiful plight-"who is guilty for the consequences of my actions?" (129)-is one that is often asked by Korolenko's Siberian nomads. In Makar's case the society which persecuted him is clearly at fault. In the story "At-Davan" the hero Kruglikov, who has been banished to Siberia from Petersburg, twice evokes this same question in the minds of listeners and readers: first, when he tells of his attempt to kill the General for stealing his fiancée from him, and second, when he demands that the ruthless outlaw Arabin abide by the rules, thereby risking his own life. In both predicaments bureaucracy and the men who manipulate it and who victimize the innocent for their own advantage emerge as guilty.

In order to decide who is guilty, one must know what is right and wrong. In all the Siberian stories this issue is examined from the moral standpoint of the hero. In the story "The Strange One" a policeman remembers his first assignment as a new recruit, which was to accompany a young, "helpless" revolutionary to her exile. He distinctly remembers his emotional involvement with this girl, whom he is willing to assist even at the risk of losing his job. Although he tries to show her that he is well intentioned, she is unable to comprehend that her sworn enemy can be truly good and refuses even to acknowledge his presence. For the hero, his own love, compassion, and care take precedence over the imposed code of conduct. In "Fedor Bespriiutnyi" the vagrant Fedor kills a sick old man who keeps following him in his wanderings. He suffers from guilt for this act, which is almost a "mercy" killing. He does not understand why he had to take such a rough path in his life-first that of a wanderer, and then that of a murderer-and wonders if he is responsible for the killing or not: "And I killed him, a sick man. ... What now, do you think? Am I answerable for it or not?" (200). Fedor is unable to free himself 
of the moral conflict within him for taking another man's life. The compassionate narrator/listener blames life for treating Fedor harshly. While Fedor is remorseful, Kruglikov in "At-Davan" does not doubt that he did the right thing when he shot at the General who stole his girl from him. He is determined to do what is ethically right whenever he finds himself in a situation that requires his judgment. This is why he single-handedly confronts the dreaded Arabin, known for his unscrupulous behavior, and demands payment for the horses he lends him. In "Iashka," the hero is fighting not for a universally accepted cause, but for something which his faith tells him is right. He is an Old-Believer and will not change his faith and belief in God and the Great Tsar to suit the changed times, even if it means he will be sent to an asylum. Clearly, these heroes are endowed with a great inner strength and a keen sense of what is right and wrong in the world where they live. Often they suffer the ill-consequences of their deliberate actions, but that does not deter them from acting according to their convictions.

Korolenko uses not only the recollections, dialogues, and actions of his heroes to reveal their inner selves; his descriptions of nature accompanying the action serve the same purpose. "The Strange One" begins with a description of a severe snowstorm which curtails the narrator's journey to his place of exile. He and the policemen who accompany him are forced to stop at a wayside inn for the night. The storm blowing in from the north disturbs the serenity of nature. The fir trees bend and sway, rain and hail strike hard, darkness falls quickly, and a biting cold settles. The turmoil witnessed in nature triggers an agitation in the hero's heart. A surge of emotions and feelings that have been buried deep within leaves him troubled and melancholy. His mood is reflected in the constant howling of the wind outside. Unable to bear the burden of his memories, the hero begins to narrate his past experience. As his story progresses, the storm slowly lets up, turning first into a steady rain and snow, and later subsiding into a drizzle and a hissing of the wind. At the end of the hero's story, the narrator, who has been listening to him attentively, says that his sleep has been disturbed by the image of the young dying revolutionary. In his mind's eye she is standing outside in the dark night while the blizzard subsides. It now appears to him as if the storm were weeping silently along with him and his companion for the unfortunate, misguided girl. Certainly, there is a parallel in nature's displays and the hero's moods, thoughts, and actions.

In the story "At-Davan" nature does not parallel the emotions of the hero as it does in "The Strange One," but it predicts at the very beginning the kind of hero that the reader will become acquainted with. The narrator, traveling along the frozen river Lena, notices a small 
spot in the current that resists the freeze, even though the ice is thick all around it. The current there seems to be forcing its way through the ice, boiling in its fury. Apparently the river never freezes at this spot. The narrator and his companion find themselves stranded and decide to rest for the night at a staging station located near the river. Once they are inside the inn, the courageous and victorious current becomes in the narrator's mind a metaphor for the hero. The hero is the station master, Kruglikov, a man small and insignificant in size, but energetic and powerful in fighting against his "invincible" enemies. He stands up for what is morally right against both the General who took away his girl and the mighty Arabin who demanded free horses for his coach. Like the river, Kruglikov withstands conflicts without regard for the consequences and marches on, bouncing off his opponent and remaining morally unscathed. (In this context it may be significant to note that his name is derived from "krug" meaning "round" like a ball, which rolls and bounces and never gets hurt, or a "bubble" in the water, which forms out of the conflicting currents in water and preserves itself by riding above the currents.)

Metaphors like the river in "At-Davan" or the storm in "The Strange One" appear repeatedly in the stories to predict, reflect, and clarify a single, powerful trait in the hero. Repeated periodically, the descriptions become a kind of refrain that lends a poetic quality to Korolenko's prose works. The miniature short story "Lights" is often called a "Poem in Prose" à la Turgenev. Even though it is the shortest piece of fiction Korolenko wrote, it serves as a good example to show how effectively the narrator with "the choice of words, construction of phrases and pauses obviously brings out the melodiousness and rhythm" (Piksanov 6). ${ }^{7}$ Here the narrator is traveling toward his destination in total darkness in a boat on the Lena. Suddenly he catches sight of lights and exclaims to the oarsman that they are close to their stop for the night. But his oarsman, wiser and more experienced, dispels this illusion by saying that their destination is still far away. This opposition between the seeming proximity and the actual distance, as it is felt by the narrator, is reproduced with the words blizko [near] and daleko [far away] alternating regularly. For example,

blizko nochleg!...daleche! [shelter for the night is near! ... Far, far away!]

Svoistvo etikh nochnykh ognei- ... i sverkat', i obeshchat', i manit' svoeiu blizost'iu ... A mezhdu tem-daleko! [The characteristic of the night lights- . . to sparkle, to promise, and to beckon with their proximity... But all the same they are far away!] 
vse tak zhe blizko, i vse tak zhe daleko ... [so close and yet so far away....]

... manili ne odnogo menia svoeiu blizost'iu ... a ogni eshche daleko. [ . . beckoned enticingly not only me with their proximity ... but the lights are still far away.] (379; emphasis mine)

This constant alternating of distance coincides with the steady rowing which thrusts the boat forward and then immediately holds it back, successfully creating the illusion of rocking for both the narrator and the reader.

The phrase "ahead there are lights" repeated at regular intervals also lends musicality to the story and emphasizes that happiness, appearing like a fleeting vision, can be attained only by proceeding through life's predetermined course. Here happiness that is realized at the end of the journey is symbolized by lights: the narrator reiterates optimistically that they, i.e., the lights, are ahead, although not very near. The pivotal phrase at the end of the first paragraph, "Vdrug ... vperedi ... mel'knul ogonek" ["Suddenly ... ahead ... light glimmered] is repeated as a constant once in the middle of the story as, "a ogonek vse stoial vperedi," ["and ahead there was light] and then at the very end with an added reassuring emphasis "No vsetaki ... vse-taki vperedi-ogni!" ["But all the same ... all the same ahead-are lights!"] (emphasis mine). But to get to those lights, which mark the end of the long arduous journey, one has to ply the oars, i.e., keep working toward the goal. This is why the words "He plied on the oars" are used soon after the narrator catches sight of the lights and again just before the optimistic end: "Anyhow there are lights ahead." Once the narrator is convinced that the lights are really far away and declares that the oarsman is right, he begins to enumerate the characteristics of these lights, which can mislead a naive, inexperienced person with the verbs sverkat' [sparkle], obeshchat' [promise], and manit' [beckon enticingly]. Here the quality of the lights to "beckon enticingly" appears to be the most striking one, because the narrator repeats it in the following paragraphs as a constant characteristic to be reckoned with in the present by using a gerund, mania [beckoning], and then as a reality in the past with the past tense manili [beckoned] (379). The action which begins in darkness with a flicker of light and hope ends on the same note, creating the circular motion that is a feature often found in poetry and music. The only difference between the beginning and the end is that the narrator moves away from his specific experience to a more general view by alluding to life's problems. In doing so the narrator removes himself from the center and describes that which attracts his attention-here it is the lights. He becomes a 
representative of all others who like him have sailed and will sail on the river in darkness, and who have been and will be duped by the lights. His optimism at the end gives rise to hope and strength to himself and his readers in the face of a grim and bleak reality.

Although the story "Lights" is short, it has all the important structural features that the other Siberian stories have. It represents a nostalgic memory which expresses a sentimental longing for that which has passed both the narrator and the character in their life's journey. While the story focuses its attention at the beginning on the narrator's impressions and feelings, it soon moves on to characterize the object of his curiosity, i.e., the lights. The narrator then becomes a minor character whose function is to describe the scene, the oarsman, the rowing, and only now and then to record his reactions to the changes he notices. The scene is described as it affects him, which is in harmony with the way it affects everyone present-in this story the oarsman and all the others who have sailed and will sail after dark on that stretch of the Lena River. Throughout the story, the surroundings-the high mountains, the dark river, and the gloomy night-reflect the mood of the travelers. The melancholy pervading the story is broken by the lights that cut through the impenetrable darkness with their unflinching strength. The lights do not succumb to exterior forces. The narrator finds a kindred spirit in the lights in this story, while in many of the other Siberian stories he meets a likeminded human being who is able to withstand the pressures of life and to stand up for his convictions and beliefs.

Korolenko's Siberian stories won him acclaim because in them he examines people who were thought to be unworthy of being heroes and he shows them to possess high moral standards suited to their own way of life. He portrays them in believable, real-life situations. The narrator who is like them in spirit-wandering, courageous, and confident-does not find it difficult to strike up a conversation. At the same time he is an outsider and differs from them because of his education. His background and his point of view enable him, however, to relate to his readers, who are generally from the intelligentsia. Besides Korolenko's choice of heroes, it is the way in which he chooses to portray them that makes his Siberian stories unique. Korolenko achieves mastery by combining nature and time to suit the characters' moods, actions, and thoughts. Some of these characteristics are also found in Korolenko's stories set in the Ukraine and in America, but they are not consistently present in all the stories of the latter cycles. At times, perhaps because they are outside the purview of the narrator's vision, the turning points in the heroes' lives are very briefly summarized, as in his story about an illiterate, Ukrainian peasant in America, "Speechless." Some of Korolenko's other tales and satires 
accurately outline a philosophical thought through dialogues, for instance in "Shadows," but they lack the elaborate ethnographic descriptions of the Siberian stories. The artistry that emerges in the creation of this cycle represents all that was new and fascinating in Korolenko's fiction. When we see them as a whole and compare them to the other cycles, it becomes clear why one critic noted that "the best that Korolenko wrote is connected to Siberia" (Tsetlin 9).

\section{Notes}

'Chekhov admired Korolenko's stories for the execution. He especially liked the story "Sokolinets" and said that it read like a "musical composition" (191). A contemporary of Chekhov, Garshin declared that he loved Korolenko's writings (375).

${ }^{2}$ Leighton also points out how Korolenko continues the traditions of Turgenev and Dostoevsky to achieve a "precise balance between social message and literary achievement" (200).

${ }^{3}$ While discussing Korolenko's narrator and comparing him to those of Tolstoy and Turgenev, Belous shows that for Korolenko nature always symbolizes either the narrator's or the character's thoughts (34).

${ }^{4}$ Kulik's study deals with themes and compositions of Siberian stories in order to show how Korolenko prepared the ground for works of Socialist Realism. The critic's claim that Korolenko portrayed the strengths of simple people by showing the "heroic moment in the simple man's life" (11) is valid.

${ }^{5}$ Isupova addresses the question of the realistic and romantic elements in Korolenko's stories. Discussing the romantic quality in these works the author explains that the nature descriptions become "symbolic overtures" (314) and lend musicality to the stories.

${ }^{6}$ The quotations from Korolenko are translated by the author of this essay.

${ }^{7}$ Piksanov also suggests that the melodiousness of Korolenko's prose is a topic yet to be researched. 


\section{Works Cited}

Belous, R. M. 'Kompozitsionnaia rol' obraza rasskazchika v ocherke-rasskaze L. N. Tolstogo i V. G. Korolenko.” L. N. Tolstoi: Stat'i i materialy 8 (1973): 30-34.

Chekhov, A. P. Polnoe sobranie sochinenii i pisem v tridtsati tomakh. Vol. 1.Moskva: Nauka, 1974. 30 vols.

Garshin, V. M. Polnoe sobranie sochinenii v trekh tomakh. Vol. 3. Moskva: Akademiia, 1934. 3 vols.

Isupova, G. A. "Romanticheskie tendentsii v russkoi literature 90-900-kh godov XIX veka." Russkii romantism. Ed. A. Guliaev. Moskva: Visshaia shkola, 1974. 310-20.

Korolenko, V. G. Sobranie sochinenii, v desiati tomakh. Vol. 1. Moskva: GIKHL, 1953. 10 vols.

Kulik, L. S. Sibir'skie rasskazy V. G. Korolenko. Kiev: Izdat. Akademii Nauk U.S.S.R., 1961.

Leighton, Lauren G. "Korolenko's Stories of Siberia." Slavonic and East European Review 49 (1971): 201-13.

Lunacharskii, A. V. Etiudy. Kriticheskie i polemicheskie. Moskva: Pravda, 1905.

Piksanov, N. "Lirizm Korolenko." Zhizn' 2 (1922): 5-15.

Tsetlin, M. "Korolenko, chelovek i pisatel' (k semidesiatipiatiletiiu so dnia rozhdeniia)." Souremennye zapiski 37 (1928): 472-81. 